\title{
DETERMINANTS OF FOREIGN DIRECT INVESTMENTS: COMPARATIVE ANALYSIS FOR BRAZIL, CHINA, SOUTH KOREA AND TURKEY
}

\author{
DOI: 10.17261/Pressacademia.2021.1436 \\ PAP- V.13-2021(25)-p.105-106
}

Fatih Kilic ${ }^{1}$, Dilek Teker ${ }^{2}$

${ }^{1}$ Kazanci Holding, Istanbul, Turkey. fatih kilic43@hotmail.com, ORCID: 0000-0003-4373-8796

${ }^{2}$ sik University, Faculty of Economics and Administrative Sciences, Department of Management, Istanbul, Turkey. dilek.teker@isikun.edu.tr, ORCID: 0000-0002-3893-4015

To cite this document

Kilic, F., Teker, D., (2021). Determinants of foreign direct investments: comparative analysis for Brazil, China, South Korea and Turkey. PressAcademia Procedia (PAP), V.13, 105-106.

Permanent link to this document: http://doi.org/10.17261/Pressacademia.2021.1436

Copyright: Published by PressAcademia and limited licensed re-use rights only.

\begin{abstract}
Purpose- With the globalization race gaining momentum after 1980, investments in developing countries increased significantly with the removal of obstacles to capital flows. With the effect of the globalization phenomenon in the world economy, developing countries have sought to meet the capitals they need with foreign investments. Until the 1980s, foreign direct investments were subject to serious restrictions. The priority of foreign direct investment was South Korea and Brazil in the early days. These two countries were followed by many emergency countries with development potential, and Turkey was trying to be included in this group. In the early 2000s, the biggest factor behind China's huge growth was the directing of foreign investments to China. In this study, inflation rate, unemployment rate and the index of industrial production, foreign direct investment coming to Brasil, China, South Korea and Turkey are examined on whether this is effective.

Methodology- The data used in statistical tests are foreign direct investments, inflation, unemployment and the industrial production index, which has the largest share in GDP and allows interpretation without GDP being announced. All monthly data used in the tests are gathered from the Reuters, Bloomberg, UCTAD and the World Bank that covers periods from January 2012 to December 2020. Initially, unit root tests were performed to determine whether the data was stable.There are 3 basic critical points to understand whether unit root tests are stationary or not. After that, the VAR model has been applied. But before that coordinates all selected variables together and examines the integrity of the system, it is required to determine the appropriate lag length in order to make assumptions correct. The are five most common methods for determining lag lengths. In order to understand whether there is a long-term relationship between variables or not that are determined to be stationary, Johansen Cointegration test has been applied. Trace Statistics and the Max-Eigenvalue statistics were used in this test. And also impulse-response functions are obtained. Variance decomposition investigates which percentage of the change in a variable is caused by itself and which percentage is caused by other variables.

Findings- All data have been converted into percentages by taking changes compared to the previous month. It has been modeled by getting the absolute values and logarithms of the data. For all 4 countries the series are found out to be stationary at level. ADF unit root test performed, then the appropriate length level determined. According to LR Test Statistics, Final Prediction Error, Akaike Information Criteria, Hannan-Quinn Information Criteria and Schwarz Information Criteria, the appropriate lang length appears as 1 . According to the cointegration test result, cointegration was determined between all countries and all data. Impulse response graphs were indicated that all variables respond in a reducing way to decreasing shocks occurred in each indicator. Shocks have lost their effect on average in 4-5 months. According to the variance decomposition results, variables were the power of explanation over each other.

Conclusion- In the Brasil, China, South Korea and Turkish economy, it is seen that there is a close relationship between foreign direct investment and economic growth indicators inflation, unemployment, industrial production index in the long term. According to the output of analyses, it is necessary to create the appropriate physical environment for increasing foreign capital investments, to ensure domestic economic, political and legal stability, to make arrangements that encourage foreign capital. Especially, a policy should be followed to decrease inflation and unemployment rates, which are indicators of economic growth and GDP should be risen by increasing industrial production. Coming from the foreign investments should become from the type of foreign direct investment and it should be supplied that these investments both create new markets and new employment areas by establishing a new facility
\end{abstract}

Keywords: Foreign direct investment, inflation, unemployement, industrial production index, VAR, impulse response JEL Codes: G10, G11, G19 


\section{REFERENCES}

Agrawal, G. (2015), Foreign Direct Investment and Economic Growth in BRICS Economies: A Panel Data Analysis, Journal of Economics, Business and Management, 3(4), p.421-424.

Canbay, Şerif ve Kırca, Mustafa (2020), “Effects of Foreign Direct Investments on Unemployment in Turkey: 1991 - 2016 Period”, Süleyman Demirel University Vizyoner Magazine, Vol: 11, p.154-163.

Karaçor, Zeynep \& Umutlu, Hasan \& Kasap, Orhan (2017),“ Foreign Direct Investments and Economic Growth Relationship”, First International Social and Economic Research Student Congress, p. 219-226.

Koojaroenprasit, Sauwaluck (2012), "The Impact of Foreign Direct Investment on Economic Growth: A Case Study of South Korea" International Journal of Business and Social Science, Vol. 3 No. 21.

Li, Ping. (2020), "An Empirical Study on Impact of Sino-South Korea Political Relations to Trade and FDI - Based on Data from Shandong Province of China", E3S Web of Conferences 189, 03021.

Mallick, Sushanta and Tomroe Moore (2008). “Foreign Capital in a Growth Model” Review of Development Economics 12: $143-59$.

Seabra, Fernando \& Flach, Lisandra (2005). "Foreign direct investment and profit outflows: a causality analysis for the Brazilian economy". Economics Bulletin, Vol. 6, No. 1, pp. 1-15.

Silveira, Eduarda Martins Correa \& Samsonescu, Jorge Augusto Dias \& Triches, Divanildo (2017). "The determinants of foreign direct investment in Brazil: empirical analysis for 2001-2003" CEPAL Review Nº 121.

Tang, Sumei \& Selvanathan, E. A. \& Selvanathan, S. (2008). "Foreign Direct Investment, Domestic Investment and Economic Growth in China: A Time Series Analysis". The World Economy j.1467-01129.

Ünsal, Mehmet Emin (2017), "FDI and Economic Growth: Comparative Analyses between Turkey and the Other OECD Countries", Journal of Current Researches on Business and Economics, Cilt: 7,Sayı: 2, s.207-216 